\title{
Knowledge, attitudes and practices about sun exposure and photoprotection in outpatients attending dermatology clinics at four hospitals in Lima, Peru*
}

Exposição solar e conhecimento, atitudes e práticas de fotoproteção em pacientes de unidades ambulatoriais de dermatologia em quatro hospitais de Lima, Peru

\author{
Elizabeth Thomas-Gavelan ${ }^{1}$ \\ Willy Ramos ${ }^{3,4}$ \\ María del Carmen Sialer ${ }^{2}$
}

\author{
Eliana Sáenz-Anduaga ${ }^{2}$ \\ Leonardo Sánchez-Saldaña ${ }^{5}$
}

\begin{abstract}
Background: To establish the knowledge, about sun exposure and photoprotection in outpatients treated at the dermatology clinics in four hospitals in Lima, Peru.

Material AND METHODS: A cross-sectional study was conducted involving a sample of 364 patients selected using a systematic random sampling process in the four participating hospitals. The selected patients were interviewed to determine their knowledge, behavior and practices in relation to sun exposure and photoprotection. The chi-square test was used to identify any significant differences between knowledge and practices.

RESUlTs: The mean age of the patients in this sample was $45.1 \pm 21.4$ years. Of the 364 patients, 55.9\% were women and $54.8 \%$ had skin phototype IV. The principal risks related to sun exposure were skin cancer (80.5\%) and sunburn (77.8\%). Knowledge regarding sun protection was more evident in individuals with university/college education ( $p<0.001)$. In addition, $78.9 \%$ of the individuals reported that they knew about photo-protectors and 52.3\% stated that they used them regularly. In general, women were more knowledgeable regarding sun protection $(p=0.001)$. Of the total number of users of photoprotection, $38.4 \%$ used these products daily, while $61.6 \%$ used them only occasionally. The use of photo-protectors differed significantly in accordance with the individual's education level $(p<0.001)$. In the majority of cases there was a statistically significant difference between knowledge and practice with respect to solar protection.

CONCLUSIONS: The level of awareness of the outpatients treated at the dermatology clinics in these four hospitals in Lima, Peru about the risks of sun exposure is acceptable; however, a large proportion fail to incorporate regular solar protection as a practice in their daily life.
\end{abstract}

Keywords: Health knowledge, attitudes, practices; Skin neoplasms; Sunscreening agents; Ultraviolet rays

Resumo: Fundamentos: O objetivo deste estudo foi determinar o conhecimento, sobre a exposição solar e fotoproteção em pacientes ambulatoriais tratados nas unidades de dermatologia de quatro hospitais em Lima, Peru.

MATERIAIs E MÉTODOs: Estudo de corte transversal. A amostra foi formada por 364 pacientes originários dos quatro hospitais participantes. Os pacientes foram selecionados através de um processo de amostragem aleatória sistemática. Uma vez selecionados, os pacientes foram entrevistados para determinação do conhecimento, atitudes e práticas em relação à exposição ao sol e à fotoproteção. O teste do qui-quadrado foi usado para determinar diferenças significativas entre conhecimento e práticas. REsultados: Os pacientes tinham em média 45,1 $\pm 21,4$ anos de idade, 55,9\% eram mulheres e 54,8\% tinham pele fototipo IV. Os principais riscos relacionados à exposição solar foram câncer de pele (80,5\%) e queimaduras solares $(77,8 \%)$. Participantes com nível universitário apresentaram maior conhecimento sobre proteção solar $(\mathrm{p}<0,001)$. O conhecimento de fotoprotetores foi relatado por $78,9 \%$ dos participantes enquanto o uso periódico dos fotoprotetores foi relatado por $52,3 \%$. As mulheres tinham conhecimento amplamente maior sobre proteção solar $(p=0,001)$. Do total de usuários de fotoprotetores, 38,4\% usavam o produto diariamente e $61,6 \%$ usavam somente ocasionalmente. $O$ uso de fotoprotetores variou significantemente com o nível de escolaridade $(\mathrm{p}<0,001)$. Na maioria dos casos se encontrou diferença estatisticamente significante entre o conhecimento sobre fotoproteção e práticas de fotoproteção.

CoNCLuSÕES: Os pacientes ambulatoriais tratados nas unidades de dermatologia desses quatro hospitais em Lima têm um nível aceitável de conhecimento mas um grande número deles não haviam incorporado práticas de fotoproteção nas rotinas pessoais. Palavras-chave: Conhecimentos, atitudes e práticas em saúde; Protetores solares; Neoplasias cutâneas; Raios ultravioletas

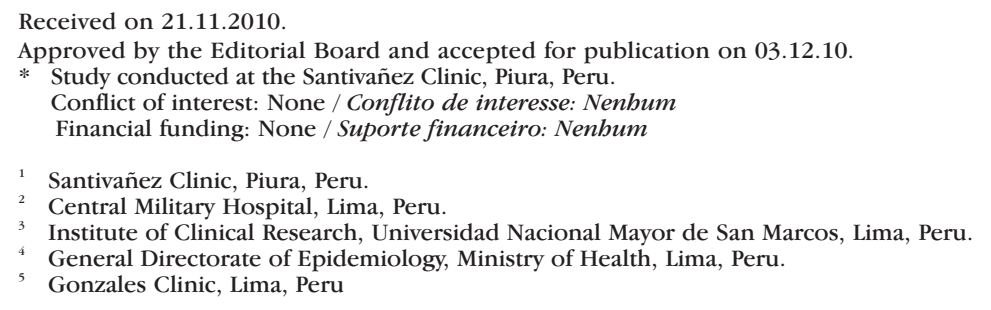

(C)2011 by Anais Brasileiros de Dermatologia 


\section{INTRODUCTION}

Ultraviolet radiation is the principal environmental factor responsible for altering skin homeostasis, affecting the survival, proliferation and differentiation of several cell types. The predominant form of ultraviolet radiation that reaches the earth's surface is ultraviolet A (UVA), with only a small proportion coming in the form of ultraviolet B (UVB). ${ }^{1}$ The progressive depletion of the ozone layer has had a major impact on the quantity of UVB rays reaching the earth's surface, which now constitutes a global concern due to an increase in the risk of UV radiationinduced mutagenesis and photo-carcinogenesis. In the southern hemisphere, where Peru is located, the ozone loss has been greater than that of the northern hemisphere; ${ }^{2}$ therefore it is important to be aware of the importance of the negative effects of an increase in ultraviolet radiation on this population.

The acute harmful effects of ultraviolet rays on the skin include damage to DNA, apoptosis, erythema, immunosuppression and an increase in pigmentation due to stimulation of melanogenesis. The long-term effects of ultraviolet radiation on the skin include photoaging and photocarcinogenesis. ${ }^{1 \cdot 7}$ Basal cell carcinoma and squamous cell carcinoma are the most common malignant tumors of the skin in the adult population, in a proportion of approximately 4:1. Non-melanoma skin cancer is minimally associated with mortality; however, it is an extremely important public health issue and its prevention and early diagnosis are constant concerns due to its associated morbidity and in terms of the functional and cosmetic changes that reduce patients' quality of life. Cutaneous melanoma originates from the malignant transformation of melanocytes. It is considered the most lethal of the skin tumors. Early detection and the latest therapeutic advances have increased survival rates; however, mortality rates continue to grow as a result of the global rise in cases. ${ }^{7-10}$

In Peru, in a study carried out by the National Institute of Cancer (Instituto Nacional de Enfermedades Neoplásicas - INEN) between 1990 and 1993 in the population of metropolitan Lima and El Callao, non-melanoma skin cancer (NMSC) ranked fourth among all the malignant tumors. ${ }^{11}$ Despite being much less common compared to other types of skin cancer, malignant melanoma cancer (MMC) has come to represent an important challenge for dermatologists, since its incidence has grown more rapidly than any other type of cancer over the past few decades. ${ }^{8}$

Epidemiological and laboratory studies have consistently shown that exposure to the sun is a preventable major risk factor for MMC and NMSC. ${ }^{12}$ It is estimated that $90 \%$ of cases of NMSC and $65 \%$ of cases of MMC worldwide are associated with exposure to ultraviolet rays. ${ }^{13}$ The use of a photo-protector is an important and prime component in solar protection strategies, which must also include the use of tightly knit clothing and hats, attempting to remain in the shade and avoiding exposure to the sun during peak hours. ${ }^{14}$ There is proof that photo-protectors have positive effects in reducing the signs of aging and the incidence of skin cancers. ${ }^{15}$

Sun exposure and photoprotection-related behavior and knowledge are important pillars in the design of skin cancer prevention strategies. Primary skin cancer prevention strategies include increasing knowledge and awareness in individuals, changing sun protection behavior and implementing environmental policies and interventions. It is estimated that the regular use of photo-protectors during childhood may reduce the incidence of skin cancer by almost $80 \%$. ${ }^{4,8,15-23}$

In Peru, during a skin cancer awareness health fair (2004), patients were asked to fill out a questionnaire, the objective of which was to evaluate knowledge, attitudes and practice about to skin cancer and skincare. This questionnaire also contained questions on sun exposure and photoprotection. ${ }^{22}$ This survey found that knowledge on the adverse effects of sunlight on the skin and the need to use photoprotection does not necessarily imply that the individual will adopt suitable measures of photoprotection.

The objective of the present study was to evaluate knowledge, attitudes and practices with respect to sun exposure and photoprotection in outpatients undergoing treatment at four dermatology clinics in hospitals in the city of Lima, Peru.

\section{METHODOLOGY \\ Design}

A cross-sectional study was performed among outpatients receiving treatment at the dermatology clinics of four hospitals in Lima, Peru: the Hospital Militar Central Luis Arias Schereiber (HMC) (the Central Military Hospital), the Hospital Nacional Dos de Mayo (HNDM), the Hospital Essalud Edgardo Rebagliati Martins (HNERM) and the Hospital Central de la Policía Nacional del Perú Luis N. Saénz (HPNP), the Central Hospital of the Peruvian Police Force.

The sample was calculated by taking the number of outpatients attending the dermatology clinics during January 2008 at each one of the four hospitals in Lima included in the study as a sample of the total population evaluated in January 2009.

Sampling was based on a known population selected using a systematic random sampling process. The sample was calculated using the following formula: 


$$
\mathrm{n}=\frac{\mathrm{N} \cdot\left(\mathrm{Z}_{\alpha}\right)^{2} \mathrm{p} \cdot \mathrm{q}}{\mathrm{d}^{2}(\mathrm{~N}-1)+\left(\mathrm{Z}_{\alpha}\right)^{2} \mathrm{p} \cdot \mathrm{q}}
$$

in which:

$\mathrm{N}=$ the outpatient population treated during the month of January 2008 at each one of the four hospitals: HNDM: 1342; HMC: 1580; HPNP: 2940; HNERM: 1261. The total population consisted of 7123 patients.

$$
\mathrm{n}=\text { Sample }
$$

$\mathrm{p}=$ Proportion of the population with knowledge regarding photoprotection $=0.5$

$\mathrm{q}=$ Proportion of the population with no knowledge regarding photoprotection $=0.5$

$\mathrm{Z}_{\mathrm{a}}=$ Critical level of $\mathrm{Z}$ with an a error of 0.05 .

$\mathrm{E}=$ Accuracy of the sample $=0.10$

The final sample was obtained by replacing the formula: HNDM: 90; HMC: 91; HPNP: 94; HNERM: 89. Therefore, the total sample consisted of 364 patients. The patients were selected using a systematic random sampling $\mathrm{k}$ interval, where $\mathrm{k}=\mathrm{N} / \mathrm{n}(\mathrm{k}=19)$ after choosing a random setup.

Inclusion criteria consisted of outpatients who were seen at the dermatology clinics of the HMC, HNDM, HNERM and HPNP. The exclusion criteria consisted of: patients who did not agree to participate in the study or who suffered from a neurological or psychiatric disorder that would have prevented them from providing reliable information.

\section{Techniques and Methods}

As soon as the respective consents were obtained at the dermatology training unit and at the clinics in each one of the four hospitals in Lima to be included in the study, a survey was performed based on a questionnaire distributed among the patients selected at each of the dermatology outpatient clinics in the four hospitals. The survey was carried out by previously trained staff members, who interviewed the patients to establish their level of knowledge and their behavior and practices in relation to the risks of sun exposure and photoprotection:

Knowledge: risks of sun exposure, skin cancer and photoprotection.

Behaviors: intentional tanning.

Practices: sun exposure, sun exposure during childhood and adolescence, present use of photo-protectors, use of other measures of photoprotection.

General information such as age, gender, education level, occupation, place of birth, place of residence, skin phototype, and family and personal history of skin cancer was also obtained.

\section{Data Analysis}

Statistical analysis was performed using the SPSS (Statistical Package for the Social Sciences) software program, version 17.0. Univariate analysis was carried out by calculating frequencies, percentages and measures of central tendency and dispersion. A bivariate analysis was carried out using the chi-square test to establish the existence of a correlation between attitudes and knowledge. Calculations were obtained with a confidence level of $95 \%$.

\section{Etbical Aspects}

Since the study consisted of a survey, no procedures were performed on the patients. The confidentiality of the data obtained was guaranteed and was used solely for the purpose of this study.

\section{RESULTS}

\section{General characteristics of the patients}

The mean age of the patients enrolled in this study was $45.1 \pm 21.4$ years (median 42 years), with only $1.1 \%$ of the sample consisting of pediatric patients (8-17 years). Overall, 55.9\% were women and $44.1 \%$ men (Table 1). In relation to education level, $30.7 \%$ had completed university and $28.8 \%$ had completed high school (Table 2). The most common occupations were homemaker $(27.7 \%)$, pensioner/retiree $(14.8 \%)$ and professionals (13.4\%). Of the total sample, $88.5 \%$

\begin{tabular}{|c|c|c|c|c|}
\hline HOSPITAL & POPULATION & SAMPLE & MEAN AGE & GENDER \\
\hline HNDM & 1,342 & 90 & $37.6 \pm 15.6$ & $\begin{array}{l}\text { Women: } 62.2 \% \\
\text { Men: } 37.8 \%\end{array}$ \\
\hline HMC & 1,580 & 91 & $49.1 \pm 29.6$ & $\begin{array}{l}\text { Women: } 37.4 \% \\
\text { Men: } 62.6 \%\end{array}$ \\
\hline HPNP & 2,940 & 94 & $41.0 \pm 14.1$ & $\begin{array}{l}\text { Women: } 66.0 \% \\
\text { Men: } 34.0 \%\end{array}$ \\
\hline HNERM & 1,261 & 89 & $53.1 \pm 19.4$ & $\begin{array}{l}\text { Women: } 58.4 \% \\
\text { Men: } 41.6 \%\end{array}$ \\
\hline
\end{tabular}
were from the Lima region, $2.7 \%$ from El Callao, $1.1 \%$

TABle 1: Sample population, mean age and gender of the patients according to hospital 
TABLE 2: Education level of the patients in the study

\begin{tabular}{lll}
\hline EDUCATION LEVEL & FREQUENCY & \% \\
\hline Graduated from university & 112 & 30.7 \\
Some university education & 37 & 10.1 \\
Technical college & 78 & 21.4 \\
Finished high school & 105 & 28.8 \\
Some high school & 12 & 3.3 \\
Finished elementary school & 12 & 3.3 \\
Some elementary school & 8 & 2.2 \\
Illiterate & 1 & 0.3 \\
TOTAL & 365 & 100 \\
\hline
\end{tabular}

from Arequipa, $0.8 \%$ from Piura, 0.8\% from Moquegua and $6.1 \%$ from other regions of Peru (Amazonas, Ayacucho, Cajamarca, Cusco, Huancavelica, Huánuco, Ica, Junín, La Libertad, Lambayeque, Loreto, San Martin, Tumbes and Ucayali).

\section{Background Information}

Most of the individuals enrolled in the study had skin phototypes IV (54.8\%) or III (26.3\%). Regarding skin cancer, $3.8 \%$ of the patients had a personal history of skin cancer and $4.1 \%$ had a family history of skin cancer. The skin phototypes of the patients are shown in figure 1 . Regarding the patient's exposure to the sun, $61.4 \%$ reported that they were exposed to the sun on a daily basis, $6.6 \%$ reported weekly sun exposure and $15.1 \%$ occasional sun exposure. The majority of patients spent approximately 1 to 2 hours (34.2\%) or less than 1 hour (34.2\%) in the sun. In terms of sun exposure during childhood and adolescent, $76.2 \%$ reported daily exposure, $8.2 \%$ weekly exposure and $14.8 \%$ occasional exposure, while $0.6 \%$ of patients were unable to establish the frequency of their exposure. Overall, $20.6 \%$ of the patients reported having suffered more than 5 episodes of sunburn over their lifetime.

Knowledge, attitudes and practices regarding photoprotection

With respect to knowledge, $93.4 \%$ of the patients reported that they were aware of the risks of sun exposure. The most frequently identified risk was skin cancer $(80.5 \%)$ as well as sunburn $(77.8 \%)$, blemishes $(74.0 \%)$, dry skin (56.4\%), freckles (55.3\%), aging (54.2\%) and wrinkles (49.9\%). A greater awareness of the risks of sun exposure was observed in the individuals with a university education $(p<0.001)$. On the other hand, with respect to an individual's awareness of the risks of sun exposure, no significant difference was found as a function of gender ( $p=$ $0.153)$ or age $(p=0.255)$. Overall, $78.9 \%$ of patients reported that they knew about photo-protectors (sun blocks and sunscreens) and $52.3 \%$ reported that they used photo-protectors regularly. Of these, the sun protection factor (SPF) most likely to be used was over SPF30 (Figure 2). A greater awareness of photo-protectors was observed in women $(p=0.001)$.

Of the 191 users of photo-protectors, $38.4 \%$ reported that they used these products on a daily basis and $61.6 \%$ occasionally. Regarding patterns of use, $62.8 \%$ reported that they used them only during the summer, $27.7 \%$ throughout the entire year and $9.5 \%$ only when it was sunny, irrespective of the season. There were statistically significant differences with respect to the use of photo-protectors as a function of education level $(\mathrm{p}<0.001)$, with use being greater in those with a university education (70.1\%) compared to those who attended only technical college $(48.6 \%)$, high school $(36.5 \%)$ or elementary

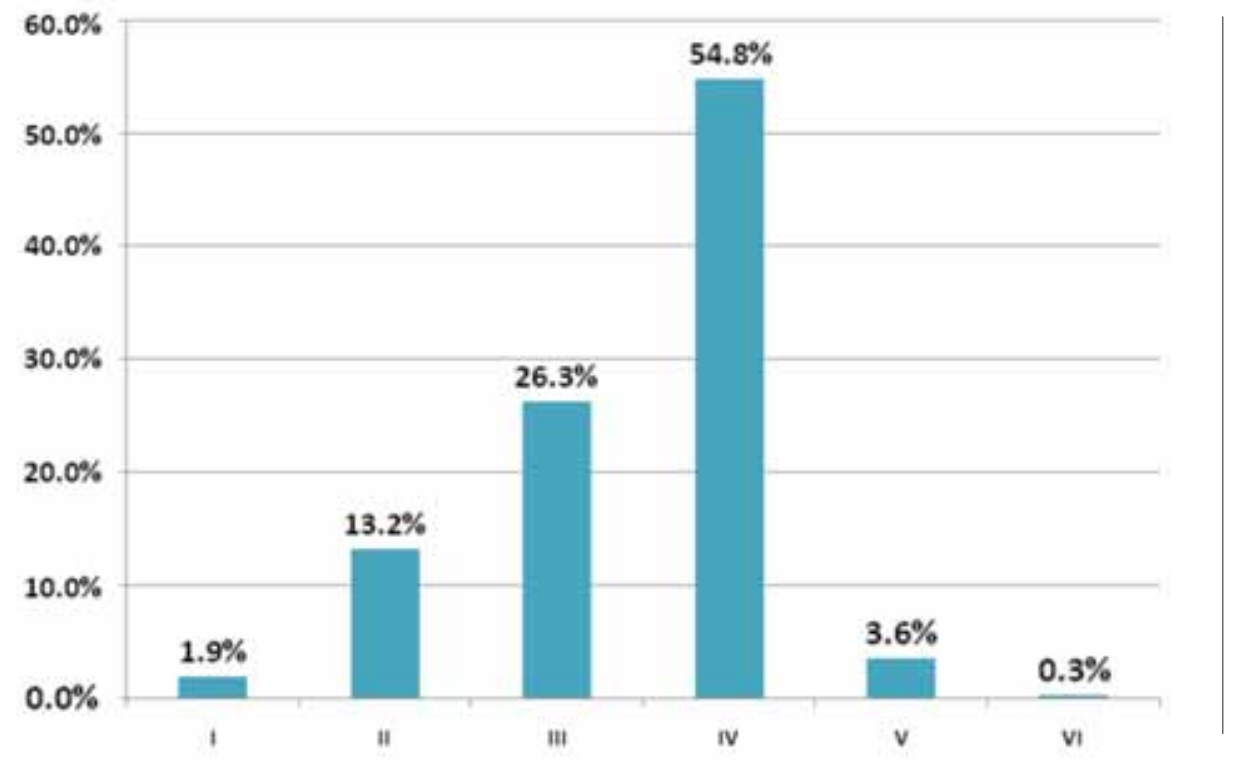

FIGURE 1: Skin phototypes of the dermatology outpatients surveyed at the four hospitals in the city of Lima 


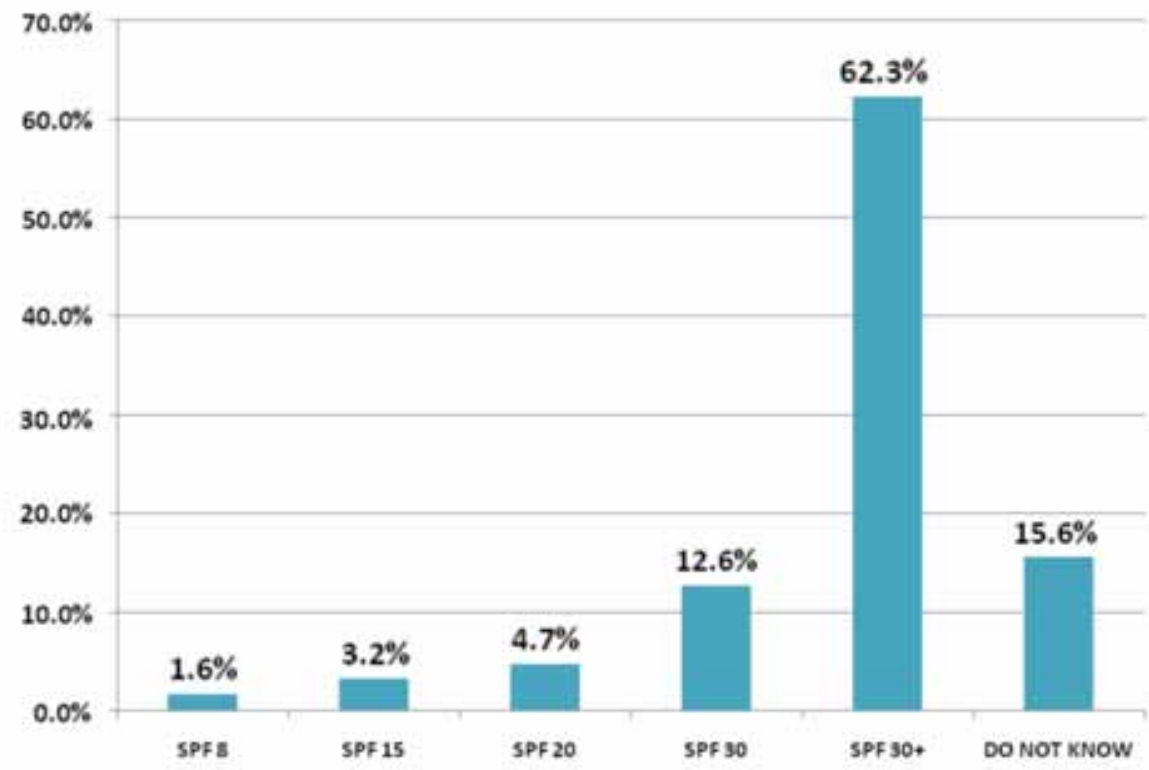

FIGURE 2: Solar protection factor (SPF) used by the dermatology outpatients surveyed at the four hospitals in the city of Lima school (36.8\%). Evaluation of the reasons given by the remaining 174 patients for not using sunblocks or sunscreens showed that the most common reasons were: not knowing about photo-protectors or considering them unnecessary for their type of skin (Table 3).

Of the entire sample of patients, $95.1 \%$ reported that they were aware of sun protection measures other than photo-protectors and 89.9\% said they used one of these measures. Awareness $(p=0.385)$ and use $(p=0.070)$ of other photoprotection measures did not vary significantly as a function of the patients' gender. In the majority of cases, a considerable difference was observed between the knowledge and practice of the patients in relation to the use of photoprotection measures. The patients were aware of the measures but did not use them. In this respect, the greatest difference concerned wearing a hat and sunglasses (Table

TABLE 3: Reasons for not using photo-protectors in the population evaluated

\begin{tabular}{lll}
\hline REASONS & FREQUENCY & $\%$ \\
\hline Unaware of photo-protectors & 56 & 32.2 \\
Unnecessary for their type of skin & 42 & 24.1 \\
Too expensive & 15 & 8.6 \\
Forgets to use & 13 & 7.5 \\
Has no photo-protectors & 7 & 4.0 \\
Does not have time & 4 & 2.3 \\
Does not like the sensation of & 3 & 1.7 \\
the photo-protector & & \\
Does not make his/her skin & 3 & 1.7 \\
look good & & 1.7 \\
Unnecessary in seasons such & 3 & 16.2 \\
as winter & & 100.0 \\
Others & 28 & \\
TOTAL & 174 & \\
\hline
\end{tabular}

4). Overall, 16.2\% erroneously believed that a suntan made them look healthier and $12.3 \%$ had a positive attitude towards intentional suntans. A significant association existed between the belief that a suntan made individuals look healthier and their attitude with respect to an intentional suntan $(\mathrm{p}<0.001)$.

The most important source of information on photoprotection reported by the patients was the media (73.7\%): television, radio, newspapers, magazines and/or the Internet. Other sources of information were healthcare staff (34.2\%), family and friends (28.2\%) and health campaigns (11.2\%).

\section{DISCUSSION}

Since Peru is situated close to the equator where levels of ozone in the atmosphere are lower than those in the northern and southern hemispheres, the Peruvian population is exposed to the risks of solar radiation. Consequently, it is important for the population to be aware of and adopt suitable photoprotection practices in order to prevent the array of skin pathologies resulting from ultraviolet radiation. ${ }^{24,25}$

This study shows that the degree of awareness of the population treated in the dermatology clinics of these four hospitals in the city of Lima about the risks caused by solar radiation is acceptable, this awareness being greater in those with university education. Furthermore, assessment of the correlation between knowledge and behavior with respect to sun protection measures revealed that despite having an acceptable degree of awareness, use of such photoprotection measures in the daily lives of this population was significantly lower.

The most relevant results included the fact that $38.4 \%$ of the individuals use sun blocks or sunscreens 
TABLE 4: Knowledge and practice of other sun protection measures by the dermatology outpatients surveyed at the four hospitals in the city of Lima

\begin{tabular}{|c|c|c|c|c|}
\hline $\begin{array}{l}\text { SUN PROTECTION } \\
\text { MEASURES }\end{array}$ & $\begin{array}{l}\text { \% of individuals } \\
\text { aware of action }\end{array}$ & $\begin{array}{l}\text { \% of individuals } \\
\text { who practice action }\end{array}$ & $\begin{array}{l}\text { \% difference between } \\
\text { knowledge and use }\end{array}$ & p-value * \\
\hline Wears hat & 89.9 & 53.4 & 36.5 & $<0.001$ \\
\hline Seeks the shade & 83.0 & 78.6 & 4.4 & NS \\
\hline Wears sunglasses & 74.5 & 43.0 & 31.5 & $<0.001$ \\
\hline $\begin{array}{l}\text { Avoids the sun between } \\
10 \text { a.m. and } 4 \text { p.m. }\end{array}$ & 70.4 & 57.5 & 12.9 & $<0.001$ \\
\hline $\begin{array}{l}\text { Wears clothing to protect } \\
\mathrm{him} / \mathrm{h} \text { erself from the sun }\end{array}$ & 50.7 & 23.0 & 27.7 & $<0.001$ \\
\hline
\end{tabular}

(*) Pearson's Chi-Square Test.

NS: Not significant.

on a daily basis; $80.5 \%$ recognized that solar radiation caused skin cancer, $52.4 \%$ related it to premature aging, while only $16.2 \%$ believed that a suntan was healthy. These results differ in certain aspects from the findings reported by Castanedo-Cazares in a population interviewed in shopping centers at San Luis de Potosí (Mexico, 2006) where $11.8 \%$ used solar protection, $85.4 \%$ acknowledged that solar radiation causes skin cancer, $83.4 \%$ related it to aging, and only $26.5 \%$ believed that a suntan was healthy. This difference in attitudes and awareness could be attributed to the fact that the present sample consisted of patients undergoing treatment at healthcare centers and who would have received further information on photoprotection from their attending dermatologists. In the case of the study conducted by Castanedo-Cazares, the sample consisted of a population of 15 years of age or older visiting shopping centers. ${ }^{26}$

Adequate use of photo-protectors remains low in this country and below rates reported in other South American countries. ${ }^{27}$ The use of photo-protectors in southern Brazil reaches as high as $60.8 \%$. In agreement with the findings reported from Brazil, the use of photoprotection found in the present study varied in accordance with the patient's education level. It is important to note that of the individuals who report using photo-protectors, a significant percentage does so on an intermittent or irregular basis. Pilot studies carried out by investigators at Boston University (USA, 2000) showed that the intermittent use of photo-protectors is associated with sun damage (sun burn cells, an increased level of perivascular inflammation, an increase in lysozyme activity in the dermis/epidermis and a reduction in the number of Langerhans cells) compared to daily use of photo-protectors, which actually reduces the harmful effects of sun radiation on the exposed skin. ${ }^{28}$ Another problem related to the poor use of photo-protectors is the amount used in each application. A study carried out in European students ${ }^{29}$ showed that, on average, indi- viduals used one-fifth $\left(0.3-0.5 \mathrm{mg} / \mathrm{cm}^{2}\right)$ of the quantity recommended by the manufacturer on the product packaging $\left(2 \mathrm{mg} / \mathrm{cm}^{2}\right)$.

According to these results, of the $52.3 \%$ of patients who used photo-protectors, the vast majority did so only occasionally or during the summer season when exposure to the sun is greater, and failed to use protection daily throughout the rest of the year. This rate is higher than rates reported previously, based on data collected at the skin cancer awareness health fair (2006). In this report, $28.6 \%$ of individuals reported using photo-protectors. ${ }^{30}$ Regarding the amount of photo-protector applied each time by users, no data are available in this country and future studies will have to be conducted to permit this aspect to be evaluated. Nevertheless, the amount used is expected to be below that reported by users in Europe ${ }^{29}$ in view of the lesser degree of awareness in the Peruvian population regarding photoprotection in addition to the cost of photo-protectors.

The most important reasons given for not using photo-protectors were unrelated to the cost of these products (that was the third most common reason). Rather, they were associated with lack of knowledge or inadequate knowledge of the conditions and methods of use, which can be resolved by providing appropriate information.

It must be taken into account that the sample surveyed in this study was recruited at dermatology clinics in four hospitals; therefore, contact with the dermatologist may have exerted a positive influence on the knowledge of the individuals surveyed. In other words, the results obtained regarding the knowledge (and therefore the practices) of the general population who do not have contact with a dermatologist and/or healthcare personnel on a regular basis may be different.

The scanty data published in this country about knowledge regarding photoprotection represents a limitation of this study. The findings of this hospital-based 
study should be supplemented with population-based studies on the prevalence of non-melanoma skin cancer and the use of photo-protectors.

In conclusion, the patients treated in the dermatology clinics of the hospitals evaluated have an acceptable understanding of the risks of sun exposure; however, a high percentage fails to adopt photoprotection measures in their daily life.

\section{REFERENCES}

1. Kadekaro A, Kavanagh R, Wakamatsu K, Ito S, Pipitone M, Malek A. Cutaneous Photobiology. The Melanocyte vs the Sun: Who will win the final round? Pigment Cell Res. 2003;16:434-47.

2. Abarca J, Casiccia C, Zamorano F. Increase in sunburns and photosensitivity disorders at the edge of the Antarctic ozone hole, Southern Chile, 1986-2000. J Am Acad Dermatol. 2002;46:193-9.

3. Brenner M, Hearing V. The protective role of melanin against UV damage in human skin. Photochem. Photobiol. 2007;83:1-11.

4. Benvenuto-Andrade C, Zen B, Fonseca G, De Villa D, Cestari T. Sun exposure and sun protection habits among high-school adolescents in Porto Alegre, Brazil. Photochem Photobiol. 2005;81:630-5.

5. Zalaudek I, Argenziano G, Soyer H, Corona R, Sera F, Blue S, et al. Three-point checklist of dermoscopy: an open internet study. Br J Dermatol. 2006;154:431-7.

6. Grandez N, Rivas L. Características clínico-patológicas de los tumores malignos de piel en el Hospital Daniel A. Carrión 1998-2001.Folia dermatol. Peru. 2004;15:11-7.

7. Ridky T. Nommelanoma skin cancer. J Am Acad Dermatol. 2007;57:484-50

8. Balato N, Gaudiello F, Balato A, Monfrecola G. Sun habits in the children of southern Italy. J Am Acad Dermatol. 2007;57:883-7.

9. Geller A, Zhang Z, Sober A, Halper A, Winstock M, Daniels S, et al. The first 15 years of the American Academy of Dermatology Skin Cancer Screening Programs: 1985-1999. J Am Acad Dermatol. 2003;48:34-41.

10. Feldman S, Dempsey J, Grummer S, Chen J, Fleisher A. Implications of a utility model for ultraviolet exposure behavior. J Am Acad Dermatol. 2001;45:718-22.

11. Registro de Cáncer de Lima Metropolitana 1990-1993. Instituto Nacional de Enfermedades Neoplásicas - INEN.1998.

12. Brown T, Quain R, Troxel A, Gelfan J. The epidemiology of sunburn in the US population in 2003. J Am Acad Dermatol. 2006;55:577-83.

13. Armstrong BK, Kricker A. How much melanoma is caused by sun exposure? Melanoma Res. 1993;3:395-401.

14. Lim H, Cooper $\mathrm{K}$. The health impact of solar radiation and prevention strategies. J Am Acad Dermatol. 1999;41:81-99.

15. Geller A, Cantor M, Miller D, Kenausis K, Rosseel D, Rutsch L, et al. The Environmental Protection Agency National Sun Wise School Program: Sun protection education in US schools (1999-2000). J Am Acad Dermatol. 2002;46:683-9.

16. Murphy G. Photoprotection: public campaigns in Ireland and the U.K. $\mathrm{Br} \mathrm{J}$ Dermatol. 2002;146;31-3.

17. Poorsattar S, Hornung R. UV light abuse and high-risk tanning behavior among undergraduate college students. J Am Acad Dermatol. 2007;56:375-9.

18. Melia J, Pendry L, Eiser JR. Harland C, Moss S. Evaluation of primary prevention initiatives for skin cancer: a review from a U.K. perspective. Br J Dermatol. 2000; 143:701-8

\section{ACKNOWLEDGEMENTS}

The authors are grateful to Dr. Alex G. OrtegaLoayza, Department of Dermatology, Virginia Commonwealth University, for critically reviewing the manuscript.

19. El Sayed F, Ammoury A, Nackhle F, Dhaybi R, Marguery M. Photoprotection in teenagers. Photodermatol Photoimmunol Photomed. 2006;22:18-21.

20. Robinson J, Rigel D, Amonette R. Trends in sun exposure knowledge, attitudes, and behaviors: 1986 to 1996. J Am Acad Dermatol. 1997; 37:179-86.

21. Pereira R, Baptista A, Fossati F, Larangeira $H$. Prevalence and associated factors with sunscreen use in Southern Brazil: A population-based study. J Am Acad Dermatol 2007; 57:73-80.

22. Catacora J, Gutierrez C. Informe final. El Día del Lunar. Folia dermatol Peru. 2004;15:77-84.

23. Romani F, Ramos C, Posso M, Rua 0, Rojas J, Siccha M, et al. Conocimientos, actitudes y prácticas sobre protección solar en Internos de Medicina de cinco hospitales generales de Lima y Callao. Folia Dermatol Peru. 2005;16:61-6.

24. Sánchez F. Consideraciones sobre la capa de ozono y su relación con el cáncer de piel. Rev Méd Chile. 2006;134:1185-90.

25. Zaratti F, Forno R. La radiación ultravioleta en Bolivia. Organización Panamericana de la Salud (OPS/OMS)-Laboratorio de física de la Atmósfera (IIF - UMSA). La Paz, Bolivia. 2003.

26. Castanedo-Cazares JP, Torres-Álvarez B, Medellín-Pérez ME, Aguilar-Hernández GA, Moncada B. Conocimientos y actitudes de la población mexicana con respecto a la radiación solar. Gac Méd Méx. 2006;142:451-5.

27. Duquia S, Baptista-Meneses AS, Reitcher S, de Almeida H. Prevalence and associated factors with sunscreen use in Southern Brazil: A population-based study. J Am Acad Dermatol. 2007;57:73-80.

28. Phillips TJ, Bhawan J, Yaar M, Bello Y, LoPiccolo D, Nash F. Effect of daily versus intermittent sunscreen application on solar simulated UV radiation-induced skin response in humans. J Am Acad Dermatol. 2000;43:610-8.

29. Autier P, Boniol M, Severi G, Doré JF. Quantity of sunscreen used by European students. Br J Dermatol. 2001;144:288-91.

30. Gutiérrez C. Informe estadístico "el día del lunar". Campaña de educación, prevención y detección temprana del cáncer de piel y melanoma-2006. Folia Dermatol Peru. 2006; 17:57-59.

\author{
MAILING ADDRESS / ENDEREÇO PARA CORRESPONDÊNCIA: \\ Elizabeth Thomas Gavelan \\ E-mail: elithomasgavelan@yaboo.es
}

How to cite this article/Como citar este artigo: Thomas-Gavelan E, Sáenz-Anduaga E, Ramos W, Sánchez-Saldaña L, Sialer MC. Knowledge, attitudes and practice with respect to sun exposure and photoprotection in outpatients attending dermatology clinics at four hospitals in Lima, Peru. An Bras Dermatol. 2011;86(6):1122-8. 